\title{
Forensic Epidemiology: Law at the Intersection of Public Health and Criminal Investigations
}

\author{
Richard A. Goodman, Judith W. Munson, \\ Kim Dammers, Zita Lazzarini, and \\ John P. Barkley
}

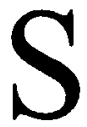

ince at least the mid-1970s, public health and law enforcement officials have conducted joint or parallel investigations of both health problems possibly associated with criminal intent and crimes having particular health dimensions.' However, the anthrax and other terrorist attacks of fall 2001 have dramatically underscored the needs that public health and law enforcement officials have for a clear understanding of the goals and methods each discipline uses in investigating such problems, including and especially the potential use of biologic agents as weapons of mass destruction. ${ }^{2}$ Recognition of these needs has prompled some experts to call for the application of "forensic epidemiology" to such problems. ${ }^{3}$ Even before the attacks of fall 2001, other problems, such as the detection of the West Nile Virus in the United States and concerns that the emergence of this infectious agent was the consequence of a deliberate act, raised novel challenges to the combined interests of public health and criminal investigators. ${ }^{4}$

In addition to demonstrating both similarities and divergences in the investigative goals and methods used by the disciplines of public health and law enforcement, the events of 2001 highlighted fundamental legal issues related to the conduct of such investigations, including both statutory bases for legal action and safeguards to individual rights and liberties. ${ }^{5}$ This paper explores the concept of "forensic epidemiology" in relation to the recent accelerated evolution of the relationships between public health and law enforcement officials during concurrent investigations, as well as selected legal issues arising or implicated in such investigations. We first consider proposed definitions for "forensic epidemiology" and then apply the

Journal of Law, Medicine E Etbics, 31 (2003): 684-700.

(C) 2003 by the American Society of Law, Medicine \& Ethics. definitions to past problems potentially illustrative of the definition. We next describe in-progress examples of the application of forensic epidemiology in public health and law enforcement program settings. We conclude by examining selected important legal issues that were identified in the context of a joint training program for law enforcement and public health officials - and have not been well described in the literature - which are important for the future cooperation of these disciplines.

\section{Defining Forensic Eptiemiology}

The term "forensic epidemiology" was used in1999 in the context of presenting the epidemiologist as an exper witness. ${ }^{6}$ However, the term's connotations relative to threats to public health were realized by at least October 1999 as part of testimony given before the Research and Development Subcommittee of the House Armed Services Committee by Dr. Ken Alibek, former first deputy chief of Biopreparat, the Soviet Union's bioweapons program?, when Dr. Alibek referred to the then recent detection of the West Nile Virus:

I cannot say it was a manmade outbreak, but ... we need to study this case very thoroughly ... I would call the signs (sic) an investigative epidemiology or forensic epidemiology to study epidemic developments, and because natural epidemics and manmade epidemics in many cases have differences. But, unfortunately, even now we cannot distinguish in many cases, because, for example, mosquitoes are perfect delivery system for some biological weapons. ${ }^{8}$ (italics added) 
In early January 2002 Dr. Julie Gerberding, then a senior official with CDC's National Center for Infectious Diseases, also addressed evolving concepts of applied epidemiology in the aftermath of the attacks of fall 2001. In remarks reported in the New York Times, Dr. Gerberding noted that: "The backbone of the Centers for Disease Control and Prevention's response to health emergencies is a corps of epidemiologists known as the Epidemic Intelligence Service. Forensic epidemiology has not been part of their training. But now it has to be ...."' (italics added)

Both Alibek and Gerberding used the term forensic epidemiology in direct relation to health emergencies and other threats to public health. However, public health's authoritative source for definitions, Last's Dictionary of Epidemiology, offers no definition for forensic epidemiology. ${ }^{10}$ What, then, are options for more clearly delineating the meaning of this term? This question can be approached by first combining the basic clefinitions of the terms "forensic" "used in legal proceedings" ") and epidemiology ("The study of the distribution and determinants of health-related states or events in specified populations, and the application of this study to the control of health problems"12), and then adapting the combination term to the contexts addressed by Alibek and Gerberding. By using this approach, two options for the definition of "forensic epidemiology" are:

- The use of epidemiologic methods as part of an ongoing investigation of a health problem for which there is suspicion or evidence regarding possible intentional acts or criminal behavior as factors contributing to the health problem; or, in the alternative,

- The use of epidemiologic and other public health methods in conjunction with or as an adjunct to an ongoing criminal investigation.

Encompassed within the development of forensic epidemiology is the newly emerging and more specific focus of microbial forensics, defined recently by the American Academy of Microbiology: "The emerging discipline of microbial forensics combines principles of public health epidemiology and law enforcement to identify patterns in a disease outbreak, determine the pathogen involved, control its spread and trace the microorganism to its source - the perpetrator(s). ${ }^{13}$ The incorporation of forensic techniques into epidemiology and other public health investigative sciences illustrates the importance and interrelatedness of epiclemiology to solving problems having law enforcement-related dimensions.

\section{Definitions of Forensic Epidemiology Applifed to Past Problems}

To examine problems occurring in the United States and illustrative of our proposed definitions for forensic epidemiology, we identified and reviewed reports published in the biomedical literature and/or in newspapers for which the nature of the problems and investigations included features encompassed by our proposed definitions (see Table 1).14 For each of these problems, the investigations involved epidemiologists and law enforcement officials, sometimes working along parallel tracks or together. The epidemiologists represented federal agencies (such as the CDC), and state and local public health agencies. Law enforcement investigators represented federal agencies (including the FBI), and state and local law enforcement agencies.

The 12 problems selected occurred during the period 1975 through 2003, and the numbers of persons potentially affected for some of the episodes were substantial, including, for example, as many as 51 cardiopulmonary arrests in 35 patients in one hospital, ${ }^{15} 751$ persons with cases of Salmonella typhimurium gastroenteritis, ${ }^{16}$ and approximately 32,000 persons initiating post-exposure antibiotic prophylaxis in conjunction with the 2001 anthrax attacks causing 22 cases of cutaneous or inhalational anthrax. ${ }^{17}$ The settings for these problems included hospitals and a nursing home, communities, restaurants, and other workplaces (e.g., media facilities, government offices, and postal facilities). The investigations examined a spectrum of problems considered at the time potentially to have involved criminal behavior, including murder, attempted murder, likely criminal assault, and bioterrorism.

The earliest of the published reports we identified involved an incident in 1975 in which an unexpected cluster of cases of cardiopulmonary arrests occurred among patients in a U.S. Veterans Administration hospital. ${ }^{18}$ In that situation, the concurrent epidemiologic and criminal investigations encompassed 51 episodes of cardiopulmonary arrest in 35 patients; urine samples obtained from three of these patients after their cardiopulmonary arrests contained pancuronium bromide, a muscle paralyzing agent, even though this agent had not been prescribed for any of them. Two of the hospital's nurses were subsequently indicted for murder, attempted murder, and conspiracy to commit murder. ${ }^{19}$

In addition to the 1975 investigation, ${ }^{20}$ episodes of cardiopulmonary arrests and/or deaths in health-care facilities appeared to cluster in the mid 1980s. ${ }^{21}$ An investigation of a cluster of cardiac arrests in patients in a surgical intensive care unit in 1985 demonstrated how a hospital's vigilance for unusual events within the hospital led first to an epidemiologic investigation, and subsequently to law enforcement conducting a criminal investigation. ${ }^{22}$ In the epidemiologic investigation, patients' increased risk of cardiac arrest was associated with having received care by 
one specific nurse. Following the law enforcement investigation, the nurse was inclicted and tried for multiple counts of murder and aggravated assault. She was convicted on one count of aggravated assault, but acquitted for all counts of murcler and 19 other counts of aggravated assault.23

Two other examples highlighting selected aspects of forensic epidemiology in these published accounts are the large community-wide outbreak of salmonellosis in 1984 in Oregon $^{24}$ and the outbreak of pesticide-related food-borne illness in California in 1998-1999. ${ }^{25}$ The outbreak of salmonellosis in Oregon in 1984 likely is the first recognized, thoroughly-investigated and documented, and reported instance of domestic bioterrorism in the United States. Following that investigation, two persons were indicted for conspiring to tamper with consumer products in violation of the federal antitampering act. ${ }^{26}$ If this incident were to occur now, the suspected perpetrators might be prosecuted under new, anterrorism federal statutes. ${ }^{27}$ In addition, this episode illustrates the relevance of the concepts of "biocrime" and "microbial forensics" as recently clescribed by the American Academy of Microbiology. ${ }^{29}$ The 1998-1999 outbreak of food-borne illness was found to be associated with a highly toxic carbamate pesticide and led to a criminal investigation by the local police department.2. The authors of the report of this investigation suggested the need to strengthen laboratory and public health capacity to recognize and control toxin-related outbreaks.

\section{Current Applications of Forensic Eptoemiology: Eptoemology aNd THE ENforcemient of Crominal Hiv Exposure Provisions}

Because of terrorist threats and attacks, public health and law enforcement officials have had to become familiar with federal laws criminalizing the use of biological or chemical agents to harm humans and, therefore, the implications of the concept of forensic epidemiology in addressing these problems. ${ }^{30}$ In addition, however, public health and law enforcement may be called upon to work together in responding to the detection of problems subject to laws that criminalize the knowing exposure of persons to certain infectious agents and diseases, such as the human immunodeficiency virus (HIV), even in the absence of intent to harm. Laws concerning criminalization associated with HIV exposure/transmission cover investigation and potential prosecution, as well as interaction between public health and law enforcement.

\section{Investigation of Persons who Knowingly or Intentionally Expose Others to HIV}

At least 27 states have enacted laws that allow prosecution for knowing or intentional exposure of others to the human immunodeficiency virus (HIV), the causative agent for acquired immunodeficiency syndrome (AJDS). ${ }^{31}$ In all states, traditional common law crimes can be used to prosecute individuals who intentionally expose or infect others with the virus (see Lazzarini et al, regarding particular characteristics of these laws and an analysis of prosecutions during 1986-2001 ${ }^{32}$ ). Epidemiology might have no role whatsoever in the initiation of a criminal case investigation under the laws allowing for prosecution of knowing or intentional exposure of HIV. An individual who realizes he/she has been exposed can bring information directly to law enforcement authorities, or evidence of exposure may arise as a part of another criminal investigation. In addition, individuals who themselves have not been exposed but who know, or believe they know, details of others' sexual activity may also contact prosecutors, who may then initiate an investigation. ${ }^{33}$

In some cases, however, epidemiological investigations may have played a key role in identifying the instances of exposure to or transmission of HIV. ${ }^{34}$ For example, in rural New York State in mid-1997, six young women with newlydiagnosed HIV infection reported having had sexual contact with the same infected man. Through voluntary partner notification and contact tracing over the next six months, approximately 1,400 persons in the county were counseled and tested for HIV. A total of 42 persons who were primary contacts of the infected index case-patient were tested; of these, 13 were HIV-positive. Testing of secondary and tertiary contacts and of infants bom to some of these women identified four additional cases of HIV infection. Of the 17 cases of infection, 16 involved heterosexual contact and one involved maternal-fetal transmission. ${ }^{35}$

In part because of the high numbers of exposures and infections, as well as other factors, this case became one of the most widely-reported instances of HTV exposure or transmission documented in the United States from 1986 through 2001 , with accounts appearing in over 700 news articles. ${ }^{36}$ Although there was no HIV-specific criminal exposure statute in New York, the inclex case was prosecuted under a traditional statute for reckless endangerment. ${ }^{37}$ Publicity surrounding this case and investigation led to two legislative attempts to adopt a new criminal exposure law, each of which failed. ${ }^{38}$ The New York state assembly did change New York's partner notification law, making reporting of contacts mandatory and requiring public health officials to notify all sexual or other contacts of HIV-positive persons. ${ }^{39}$

Epidemiologists also have been called as expert witnesses in exposure or transmission cases to testify on issues such as the likelihood of transmission by various modes of exposure..$^{10}$ In cases where the "exposure" underlying the criminal charge was biting or spitting, epidemiologic testimony may indicate the very low probability of actual transmission. ${ }^{41}$ However, since epidemiologists have been reluctant to rule out the possibility of 
transmission, such testimony may paradoxically support prosecution for very low risk activity. As noted elsewhere, the languages of science and criminal law are not always easily compatible. As a result, prosecutors and juries may have a difficult time applying epidemiologists' testimony concerning association, causation, and risk.

\section{Law Facilitating Coordination Between Public Health and Law Enforcement}

Although New York, in the aftermath of the above-described case, did not adopt an HIV-specific criminal exposure law, other states did. South Dakota, for example, in 2000, enacted a new law that makes knowing exposure of others to HIV a felony punishable by up to 15 years in prison. ${ }^{42}$ One of the first persons charged under this law was a college freshman who eventually pleaded guilty to having had sexual intercourse with his girlfriend after he learned he was HIV-infected, ${ }^{43}$ and at least two other men have been charged under this new law. ${ }^{44}$ The process of investigating these incidents exposed what South Dakota health authorities believed was a problem - that health authorities were required to protect confidential HIV information even when they believed an infected person might be having sex withour disclosing his or her infection status.

As the result of recognizing this issue involving confdentiality, the South Dakota Department of Health supported introduction of a new provision to allow disclosure of confidential HIV testing information from the Department of Health directly to law enforcement authorities:

"(5) To the extent necessary to comply with a proper judicial order requiring release of human immunodeficiency virus test results and related information to a prosecutor for an investigation of violation of sec 22-18-31 [Intentional exposure to HIV a felonyl; and

(6) To the attorney general or an appropriate state's attorney if the secretary of the Department of Health has reasonable cause to suspect that a person violated $\mathrm{Sec} 22-18-31 . "$

The bill was approved by both houses of the state's legislature and signed into law by the Governor on March $20,2003 .{ }^{45}$ This new law redefines the role of public health in relation to criminal prosecution of HIV exposure or transmission. Particularly in subsection (6), the law clearly places health authorities one step closer to an enforcement role by giving the Secretary discretion (based upon undefined criteria) to determine when there is reasonable cause to suspect that an individual has continued to expose others.

An important issue raised by the South Dakota law, which may also have ramifications for other jurisclictions, is whether an association of public health with law enforcement is to the detriment of routine public health practice. For example, and as noted above, under South Dakota law, public health personnel counseling someone who wants to be tested must tell the individual that information about a positive test will be disclosed to law enforcement if the Secretary has reason to believe that the individual is having sex (or sharing needles) without disclosing his or her HIV status to sex (or shared needle) partners. Possible effects of notification of the potential disclosure of HIV test informaltion to prosecutors are that some persons may be less likely to be tested; some may not return to receive their test results; or, some will refuse to disclose their current sexual or needle-sharing partners to health authorities.

Although public health personnel may offer assurances that disclosure represents an option of last resort ("disclosure would be limited to HIV information only and would be necessary only when all other public health control measures have failed and the infected individual has displayed a disregard for the law and remains non-compliant" ${ }^{166}$ ), that possibility may nonetheless be sufficient to deter any further contact with public health officials, especially if the index patient has identified contacts with commercial sex workers, multiple partners, or needle-sharing partners, any of which may have moral or criminal overtones. Moreover, provisions that allow disclosure of confidential public health data to prosecutors without the intermediary of a court could raise public concern over the confidentiality of other public health data. Thus, one potential consequence of such cooperation between public health and law enforcement is that some persons might fear that other public health data will be disclosed directly to law enforcement, with or without a court order. (This issue also is addressed in a later section of this paper, "Disclosure of confidential health information by public health to law enforcement".)

\section{Current Appucations of Forensic Epidemology: The Example of JoInt Training for Law Enforcement and Pubuc Health Officials}

Events of fall 2001 - including the anthrax attacks and the thousands of biologic threats and hoaxes - required law enforcement, public safety organizations, and public health agencies to work together in ways without precedent, even taking into account the examples given previously. Although the concurrent responses to these more recent threats affirmed the many similarities in the goals and investigative methods used by both law enforcement and public health officials, salient differences also were recognized in the different disciplines' approaches. To foster improved understanding of the investigative goals and methods specific to each discipline, and to strengthen interdisciplinary collaborative effectiveness in response to future attacks 
involving biological and chemical agents, the Centers for Disease Control and Prevention, (CDC) in partnership with other agencies, undertook development of a "Forensic Epidemiology" course for the joint training of law enforcement and public health officials.

A primary goal for the "Forensic Epidemiology" training course is to enhance the joint effectiveness of law enforcement and public health when both disciplines conduct concurrent criminal and epidemiological investigations, respectively, in response to a threat or attack involving possible biological or chemical agents. The course objectives cover key topics in the basic areas of: (1) criminal and epidemiological investigative methods; (2) operations and procedures; and (3) communications. These three areas, in turn, encompass a spectrum of specific operational and legal issues (see Table $2^{47}$ ).

The course addresses its primary goal by bringing together equal numbers of law enforcement and public heath officials who sit side-by-side for 1-1/2 days to interact directly while working through three fact-based scenarios involving threats and attacks with potential biological agents. As preparation for working through the three fact-based case scenarios, all participants in forensic epiclemiology training are given background information on each professional discipline's approaches to investigative responses. The domains essential to working through the scenarios are principles of public health and epidemiology (geared to the law enforcement and public safety participants), principles of law enforcement and criminal investigations (geared to the public health participants), the roles of the public health and crime laboratories, and coordination of joint investigations from the federal perspective of the FBI.

The fact-based case scenarios used for this training were developed around real events as a means for assuring that the operational and legal issues that surface cluring the training are grounded in reality. In addition, the scenarios were selected because they represent a spectrum of categories of bioterrorism-and chemical-related threats and problems likely to confront law enforcement and public health officials, including overt (announced) and covert (unannounced) incidents. The specific incidents repsUsent: (1) an overt scenario - the receipt of a "white powder" letter by which the explicit threat announced itself; (2) a covert/overt scenario - the initial recognition in Florida of the anthrax attacks of October 2001 in which the problem first presented as one of possible naturally-occurring origin, but soon thereafter was recognized as having intentional and criminal origins ${ }^{48}$; and (3) a covert scenario the 1984 outbreak of Salmonella Typhimurium gastroenteritis which presented and was investigated as a naturally occurring outbreak, but for which criminal intentionality was suspected only at a later stage in the investigation. ${ }^{49}$

In addition to the course's defined objectives (see Table 2), this training approach enables consideration of a host of related legal and operational questions. Foremost is the issue of defining and clarifying the implications of the laws of entry into premises and workplaces during concurrent public health and criminal investigations. Another example relates to the now lowered threshold for considering the causal contribution of deliberate criminal behavior to the origin of a public health problem and related implications for the "covert/overt" scenario - that is, an event initially considered to be naturally occurring (or at least of deliberate but non-criminal origin), but which subsequently is re-classified as having potential criminal origins. Under these circumstances, critical questions that arise are: at what point during an investigation would roles shift in terms of which discipline is in the lead; what are the implications of a shift in lead; and what are the specific relevant constitutional, statutory, and other laws that apply to the problem?

The "Forensic Epidemiology" course was designed by $\mathrm{CDC}$ to stand as a self-contained instructional template for use in any U.S. jurisdiction. The course initially was implemented in November 2002 in North Carolina, where planning and cosponsorship involved a model partnership of state and federal law enforcement and public health organizations, including the the state health department, the state bureau of investigation, the state's field office of the FBI, a U.S. Attomey's office, and a school of public health. Participants represented the co-sponsoring organizations, as well as local and state law enforcement, public health, and other governmental and professional organizations, and the judiciary. The course was further piloted in other jurisidictions, before being released for use nationally at a U.S. Department of Justice-sponsored meeting in spring 2003. Additional information regarding the availability of this training resource is available at www.phppo. cdc.gov/od/phlp.

\section{Current Applications of Forensic Epidemiology: Legal Issues Arusing in Operations and Training}

The accelerated interactions between law enforcement and public health, especially in the setting of joint investigations of threatened or real attacks with biological and chemical agents, have raised a host of issues and questions. These issues concern the application and operation of legal authorities - including federal and state, and criminal and civil - in such situations. Recognition of these issues and questions also has highlighted the need for methods, such as the forensic epidemiology training as described above, to deliver education regarding the law to public health officials and others with responsibilities for responding to and investigating bioterrorism incidents, but who do not have backgrounds in law. Examples of such legal issues and questions include the law(s) surrounding the gathering of admissible evidence during public health investigations, 
access to premises (i.e., the law of entry), establishing and maintaining a chain of custody of evidence, disclosure of confidential health information by public health to law enforcement, and restricting a person's freedom of movement following exposure to communicable diseases.

\section{Gathering Admissible Evidence in Public Health Investigations}

Regardless of whether an intentionally unleashed biological threat is accompanied by an open and notorious announcement, such as the express threat contained in the September 2001 anthrax-laced letter to Senator Tom Daschle (the letter sent to Senator Daschle contained seven lines of block lettered text, stating "You cannot stop us. We have this anthrax. You die now. Are you afraicl? Death to America. Death to Israel. Allah is great." ${ }^{10}$ ), or is introduced so as to mimic a naturally-occurring outbreak (e.g., like the circumstances of the 1984 Salmonella Typhimurium outbreak in Oregon $\left.{ }^{51}\right)$, the successful prosecution of the perpetrators of such crimes will require admissible evidence. In gathering evidence, government agents must comply with, among other things, the Fourth Amendment prohibition against unreasonable searches and seizures and the Fifth Amendment protection against self-incrimination. The Fourth Amendment guarantees that:

The right of the people to be secure in their persons, houses, papers, and effects, against unreasonable searches and seizures, shall not be violated, and no Warrants shall issue, but upon probable cause, supported by Oath or affirmation, and particularly describing the place to be searched, and the persons or things to be seized..$^{52}$

In addition, the Fifth Amendment to the Constitution provides, inter alia, that "Inlo person ... shall be compelled in any criminal case to be a witness against himself. ${ }^{53}$

The Fourth and Fifth Amendments to the U.S. Constitution apply only to government-sponsored actions; therefore, public health officials, like all government agents, must conform their investigations to constitutional standards. In Camara v. Municipal Court, ${ }^{54}$ the United States Supreme Court expressly overruled its prior case, Frank v. Maryland, ${ }^{55}$ which had held that a city's health department inspectors did not need a search warrant to conduct routine health inspections. In so doing, the Court held that the "one governing principle ... [is that] except in certain carefully defined classes of cases, a search of private property without proper consent is 'unreasonable' unless it has been authorized by a valid search warrant." 16 Camara and the case of See v. City of Seattle are companion cases, which the Coun heard together: Camara addressed warrantless, unconsented entry into a residence, and See examined the same issue with regard to a business. After See, inspections of businesses that are not subject to specific and pervasive regulation must be conducted pursuant to a search warrant, unless some recognized exception to the warrant requirement applies.

Because public health officials do not typically investigate criminal activity, the greatest potential for the inadvertent gathering of evidence that later could be excluded from trial because of a constitutionally invalid search or seizure may exist when a public health official is leading the investigation at the time the evidence is obtained (i.e., when a public health official is investigating a public health event and law enforcement is either present, but passive, or is absent). Examples might include when a public health investigation is ongoing before authorities realize that the particular public health event resulted from a potential criminal act; where public health and law enforcement are conducting parallel investigations, even if a law enforcement official is technically in charge; or where a public health official is conducting an investigation and is accompanied by a law enforcement officer who does not take an active part in the investigation occurring at that time.

\section{Fourth Amendment Requirement that Any Search or Seizure Must be Reasonable: the Law of Entry and Seizure of $A$ Person}

Whether the entry onto private property is for criminal investigative or administrative purposes, the overarching protection covering the expectation of privacy in homes, workplaces, and businesses is found in the Fourth Amendment's prohibition against "unreasonable searches and seizures." ${ }^{57}$ (See also: O'Connor v. Ortega, which presents an analysis of what might constitute a reasonable expectation of privacy in the workplace in addressing this issue with respect to a professional employee of a governmental hospital. ${ }^{\text {st) }}$ A search is reasonable if performed pursuant to a warrant or pursuant to a judicial exception to the warrant requirement. Evidence gathered as the result of an unreasonable search is subject to the exclusionary rule, the remedy for which is generally the inadmissibility of that evidence in a criminal case (see Weeks v. United States, and Gouled v. United States ${ }^{5 \%}$ ).

\section{The Warrant Requirement}

The Fourth Amendment itself defines a warrant-based search as a reasonable search. Public health investigations do not typically seek evidence of criminal activity. Instead, common purposes of public health investigations include, for example, detecting and remediating biological, chemical, or other threats to community health; developing information regarding risk factors for the occurrence of diseases, 
injuries, and disabilities; and providing a scientifically rational basis for implementing prevention and control measures. These purposes may require public health officials to make entries to obtain samples of substances that may pose a threat to public health, conduct inspections, or to alleviate hazardous conditions. Entry also may be sought in response to a complaint, in furtherance of a regulatory scheme, or pursuant to an enforcement provision in a statute or ordinance. As previously noted, however, any entry must conform to constitutional standards.

Entries for the aforementioned purposes by representatives of a governmental public health agency generally are referred to as "administrative searches," to distinguish them from searches by law enforcement personnel seeking evidence of criminal activity for which the perpetrator can be prosecuted. Administrative search warrants are often viewed as requiring a "lower standard" of probable cause than criminal searches. ${ }^{60}$ In administrative searches, probable cause is supported not by the traditional definition of likelihood to believe that evidence of a crime will be found in the area to be searched, but rather probable cause is satisfied by "reasonable legislative or administrative standards for conducting an area inspection ... with respect to a particular dwelling. ${ }^{n 11}$ The case of Michigan v. Clifford distinguishes the two types of warrants:

If the primary object is to determine the cause and origin of a recent fire, an administrative warrant will suffice. To obtain such a warrant, fire officials need show only that a fire of undetermined origin has occurred on the premises, that the scope of the proposed search is reasonable and will not intrude unnecessarily on the fire victim's privacy, and that the search will be executed at a reasonable and convenient time. If the primary object of the search is to gather evidence of criminal activity, a criminal search warrant may be obtained only on a showing of probable cause to believe that relevant evidence will be found in the place to be searched. ${ }^{62}$

For public health investigators, the difficulty arises when, in the course of an administrative search, evidence of a crime is found.

Several court decisions have given direction on the admissibility of evidence of a crime discovered during an administrative search. In Michigan v. Clifford, when fire officials went to the scene of a fire to investigate the cause, they found evidence of arson. The Court set specific parameters for the administrative nature of the search as it evolved into the criminal arena and restated the requirement for a search warrant issued pursuant to probable cause, noting that the "plain view" doctrine might come into play, such that "[i]f evidence of criminal activity is discovered during the course of a valid administrative search, it may be seized under the 'plain view' doctrine. This evidence then may be used to establish probable cause to obtain a criminal search warrant. ${ }^{163}$ In the case of the United States v. Branson, the court of appeals upheld the seizure of marijuana that motor vehicle inspectors found when conducting a warrantless search of a body shop pursuant to state statute that permitted business records inspections during work hours. ${ }^{64}$ Other cases have upheld or rejected administrative searches. ${ }^{65}$

\section{Exceptions to the Warrant Requirment}

Courts have found that, in some circumstances, searches predicated on something besides a warrant also can be reasonable. In an epidemiological investigation, three oft-used exceptions to the warrant requirement are likely to be: (1) where a person with authority consents to the search; (2) where exigent circumstances compel immediate action on the part of the government agent; or (3) a search of a workplace or business that is part of a "pervasively regulated industry". ${ }^{6}$

\section{(1) Consent}

In a warrantless search based on consent, a government official may properly conduct a search and, accordingly, seize evidence, where a person with either actual or apparent authority over the area to be searched voluntarily consents. Actual consent is self-explanatory. A warrantless search based on consent given by a person with apparent authority is also proper where the agent incorrectly, but objectively and subjectively reasonably believed that the person consenting had the authority to do so ${ }^{67}$ Consent to search is not valid unless, under the totality of the circumstances, the consent was given voluntarily. ${ }^{68}$

\section{(2) Exigent circumstances}

Exigent or emergency circumstances exist "when there is compelling need for official action and no time to secure a warrant. ${ }^{169}$ It is important to note that exigent circumstances alone are not enough to justify a warrantless search and seizure; probable cause must also be present. Thus, the three factors that must be present to justify a warrantless search or seizure under exigent circumstances are: (1) probable cause; (2) compelling need for official action; and (3) insufficient time to secure a warrant. ${ }^{70}$ Probable cause usually is defined as the "fair probability that contraband or evidence of a crime" will be found in the suspected place. ${ }^{71}$ The requirement that there be a compelling need for official action is closely tied to the need for immediate action. In short, there must be an inherent and immediate danger arising from the suspected situation. ${ }^{72}$ The legal determination of whether 
exigent circumstances exist is necessarily fact-specific, being heavily dependent on the factual events surrounding a particular search or seizure. In the public health arena, courts have upheld warrantless searches and seizures based on exigent circumstances, including the need to seize diseased livestock, compel vaccination, seize tainted food, and quarantine individuals with communicable diseases. ${ }^{73}$

\section{(3) Pervasively-regulated businesses}

The Supreme Court addressed workplace-related considerations in New York v. Burger, in which the closely regulated industry (this phrase is often used interchangeably with "pervasively regulated businesses") was a junkyard. ${ }^{74}$ Because vehicle dismantlers whose premises were searched were part of a closely regulated industry, there was a reduced expectation of privacy and a warrantless search of the commercial premises was upheld. The pervasive regulation that would render a warrantless search valid, however, must be specific to the industry searched and not applicable to business premises generally. "The exception of pervasively regulated businesses applies to enterprises that are so thoroughly regulated, and which in some instances have been regulated for a long time, so that any person who engages in the business gives up any 'justifiable expectation of privacy'."'76

\section{Scope of Search}

Where a public health official seizes evidence without a warrant in what is or what will become a criminal case, a central issue is likely to be the scope of the search preceding the challenged seizure. For example, where a public health official properly enters a house pursuant to an administrative search or under the relatively rare exigent circumstances doctrine, there would probably be no wholesale right to do a thorough search of the house, such as opening drawers and cabinets. If the public health official saw something in plain view that justified a more thorough search, the official could alert law enforcement, who would then secure the building and get a search warrant based on the probable cause generated from the evidence discovered during the justified warrantless entry. In United States v. Moss, the court of appeals held that even if a park ranger justifiably entered a rented park cabin without a warrant on the grounds that he feared the occupants might have been hurt, the search of the occupant's backpack was unconstitutional because it was "completely outside the legitimate range of any search justified by thlel particular 'emergency' purpose."

\section{Seizure of A Person}

A public health official can also effectuate a "seizure" of a person during an interview. Generally, seizure or custody occurs during an interview when "in view of all of the circumstances surrounding the incident, a reasonable person would have believed that he was not free to leave." ${ }^{178}$ In a recent case, social workers unlawfully seized a boy whom they suspected of being abused when they took him from his private school classroom and, in the presence of a police officer, asked the boy questions. ${ }^{72}$ In this instance, the case worker conducted the interview pursuant to a state law that provided that a child welfare worker investigating $s$ uspected abuse may "interview the child at any location without permission from the child's parent, guardian or legal representative." The Court held that the seizure did not fall under the exigent circumstances exception becaluse the investigation had been ongoing for some time and the state did not claim that the child was in immediate danger; accordingly, the seizure was unreasonable. ${ }^{80}$

A situation can readily be hypothesized where a public health official is leading an interview in the presence of law enforcement during an investigation of a suspected intentional event involving a biological agent. In such a case, the argument would be that the interviewee was in custody and was unconstitutionally seized. The determination of whether the person was indeed in custody, such as he would not feel free to leave, would turn on the facts surrounding the interview, such as whether a law enforcement officer was present when the interview took place. (In Doe, a civil suit, the fact that the interviewee was a child could be a deciding difference between that case and one where a public health official was interviewing an adult.)

\section{The Fifth Amendment: Statements Made By a Suspect in Custody}

Issues regarding constitutional protections against self incrimination could arise during epiclemiologic investigations of public health and other health-related problems possibly resulting from criminal activity. Such issues might arise, for example, if public health officials, during the course of an otherwise seemingly routine outbreak investigation, interview persons who were affected by the health or disease problem, but who themselves may come to be considered suspect perpetrators. A more likely situation in which this issue might arise would be when a law enforcement officer also is present during an interview.

A person has a constitutional right under the Fifth Amendment not to incriminate him- or herself. The familiar Miranda warnings serve as a safeguard to protect a person's Fifth Amendment right. ${ }^{81}$ Thus, before conducting a custodial interview, a government agent must inform the interviewee of his Fifth Amendment right against selfincrimination and his due process right to counsel. When a government agent fails to provide Miranda warnings to a person interviewed while in custody, the statement generally 
may not be used as evidence. ${ }^{82} \mathrm{~A}$ custodial interrogation is defined as questioning "after a person has been taken into custody. ${ }^{183}$ In deciding whether the statement must be suppressed, the key questions are whether the declarant making the statement was in custody and whether he or she was being interrogated at the time the statement was uttered. The requirement that the statement be made under interrogation insulates spontaneous statements from suppression. A suspect, for example, who simply volunteers immediately after atrest that he has a biological agent in his basement would not be under interrogation.

Custody generally occurs when, because of a show of government authority, a reasonable person would not feel free to leave. The issue of custody could arise, for example, in a serting in which a potential suspect has clinical manifestations of exposure to the same infectious or chemical agent that he is suspected of having disseminated, and a public health official conducts a hospital bedside interview in the presence of a law enforcement officer. In such a case, the test as to whether the interview was conducted in custody would depend not on whether the person felt free to leave, because, obviously, freedom to leave the hospital would be restricted. Rather, custody would depend on whether a reasonable person would feel free to decline to answer the questions posed (see Florida v. Bostick, in which the Supreme Court held that where a person did not feel free to leave because of circumstances independent of agent presence, such as in the confines of a bus, the broader test of whether a reasonable person would feel free not to answer applies ${ }^{\text {th }}$ ). This issue would raise the same type of fact-intensive inquiry necessary to determine the voluntariness of consent.

As in the Fourth Amendment context, an emergency can negate the Fifth Amendment requirement that Miranda warnings be given prior to a custodial interview. Where, for example, a suspect is caught in the act of making a bioterroristic threat of immediate danger, a question as to where else the person released the biological agent would be proper even before any constitutional wamings are given. This stems from cases holding that a "public safety" exception applies to custodial questions posed in an attempt to avert an immediate threat (see: New York v. Quarles, in which the Court held that non-Mirandized questioning of an arrested suspect about the location of the gun that he was seen carrying just minutes before his arrest fell under the public safety exception ${ }^{85}$ ).

\section{Chain of custody of evidence}

To be admissible in a criminal prosecution, evidence gathered during an investigation must be properly maintained from the time it is discovered until presentation in the courtroom. Uncertainty about how a particular sample was obtained, stored, maintained, or tested can result in the evidence being ruled inadmissible, or, even if admitted, in the jury discounting the evidence and questioning the credibility of the officials who handled the evidence.

For tests on fungible objects (i.e., objects that carry no obvious unique identifying mark) to be considered by a court or jury, it must be shown that the object tested was adequately protected from tampering from the time it was collected to the time it was tested, and that the object tested was indeed the same as the object collected. Likewise, where the object itself is to be submitted into evidence, this must be established from collection until its appearance in court. Properly laying this evidentiary foundation requires establishing a chain of custody. To adequately establish a chain of custody there must be a system in place that identifies every person who handled the evidence. Additionally, every person who handled the evidence should be able to testify about the following factors:

- How she/he initially received the object/ sample/evidence (i.e., from whom did she get it from and how did it arrive).

- How Standard Operating Procedures (SOPs) work to safeguard the object/sample/evidence from tampering, including factors like keeping the sample in an evidence locker that is locked and has limited access.

- What the person testifying did with the object/ sample/evidence after she/he was through with it (i.e., did they retain, dispose of, or transfer it).

- That the object in the courtroom was the same object that she/he handled.

- That the object in the courtroom is in the same condition as when he/she handled it. ${ }^{26}$

Each person who handled the object should be able to produce or explain documentation that supports the above points. Thus, the official who first collects the sample should complete some type of receipt of property form, on which the object is described in simple terms, without opinions or remarks. For example, the notation "small vial containing white powder" would be proper, while the notation "suspected anthrax" would not be.

Anyone who takes custody of the sample should make an entry onto a chain of custody form, which documents the transfer of the sample from one person to another. SOPs should be written to ensure limited access to any particular sample. Documentation must be kept as to how the item was disposed of or to whom it was transferred. To enable a witness to testify that the object in the courtroom is the same one that she or he handled, there must be some type of marking system. Identifying numbers on a petri dish, bar codes, and placing the sample in a sealed, marked plastic bag are examples of simple marking systems. 


\section{Disclosure of confidential health information by public health to law enforcement}

In the aftermath of the September 2001 terrorist attacks, some state legislatures undertook assessment and revision of statutory provisions regarding the response capacities of public health and law enforcement agencies. ${ }^{87} \mathrm{An}$ example of one important issue at the cross-section of protecting community health, safeguarding inclividual interests, and assuring due process is that of the possible need for public health to disclose to law enforcement confidential, personal information obtained by public health.

In North Carolina, the legislature addressed this issue in the context of joint public health and law enforcement investigations by enacting expanded powers for the State Health Director to investigate suspected terrorist incidents involving nuclear, biological or chemical (NBC) weapons. ${ }^{8 B}$ The legislation also authorized the Director to gather otherwise confidential medical information that might assist in the epidemiological investigation of cases of communicable diseases indicating a terrorist incident. ${ }^{80}$ Part of the changes made to aid in the investigation of a terrorist incident reflected a recognition that otherwise confidential medical information protected by a strict confidentiality statute (N.C.G.S. 130A-143) may need to be shared with law enforcement in order to investigate, and perhaps prevent, a terrorist attack, or to allow law enforcement to assist the public health agency in preventing the spread of a communicable disease as the result of a terrorist incident. ${ }^{90}$ Therefore, the legislature included a specific exception to its confidentiality statute that allows the sharing of otherwise confidential medical information with law enforcement officials regarding persons who have or may have a communicable disease. Such information may be shared with law enforcement officials only for enforcement of communicable disease control statutes or of public health statutes specifically addressing the use of NBC agents as part of a terrorist incident, or when law enforcement is "investigating a terrorist incident using nuclear, biological or chemical agents." ${ }^{\text {"II }}$ In addlition, the law prohibits further disclosure of such information by law enforcement officials except "when necessary to" enforce the public health laws, conduct an investigation of a terrorist incident involving NBC agents, or "when the Department or a local health department seeks the assistance of the law enforcement official in preventing or controlling the spread of the disease or condition and expressly authorizes the disclosure as necessary for that purpose." "y?

\section{Restricting Freedom of Movement in Response to Public Health Emergencies}

Bioterrorism and other public health emergencies also require law enforcement and public health officials to cooperate in the implementation of a variety of legal interventions. For example, another problem North Carolina's legislature addressed recently is the dilemma faced when a person violates a public health order restricting their freedom of movement because they have, or may have been exposed to, a communicable disease. Under North Carolina law, violation of such an order is a criminal act, punishable by up to two years imprisonment. ${ }^{93} \Lambda$ person who violates the order and attempts to leave the restricted area designated by the State Health Director may be arrested. Under such circumstances, law enforcement would place the person in jail to await a preliminary hearing and, if a judicial official found probable cause for the charges, release the person on bail or return the person to jail to await trial. However, if the person is in a communicable stage of a disease such as smallpox, then release to the community or detention within the jail population could pose serious adverse consequences. Therefore, the legislature included provisions allowing law enforcement to detain a person arrested for violation of such an order in the area designated by the State Health Director in her order until an initial appearance before a judicial official. ${ }^{94}$ If a judicial official conducting the initial appearance found, by clear and convincing evidence, that the person posed a threat to the public's health, then the judicial official must deny bail and detain the person in an area designated by that official in consultation with the State Health Director. ${ }^{95}$ The legislature adopted this approach to protect the person's due process rights without putting the public's health at risk.

\section{Conciusion}

In this paper, we have suggested definitions for the term "forensic epidemiology" in the context of investigative responses to public health events possibly associated with criminal activity. In addition, we have presented examples of problems and previously reported investigations to which this definition might be applied, as well as described an approach to conducting related training and considering salient legal issues. As noted, the concept of forensic epiclemiology appears to have applicability as early 1975 , in the setting of the investigation of the cluster of cardiopulmonary arrests in a Veterans Administration hospital. ${ }^{96}$ However, more recent events involving the deliberate, criminal use of biologic and toxic agents ${ }^{27}$ underscore the needs for strengthened and better informed collaboration between public health and law enforcement criminal investigators, and clearer understanding of the powers of and limitations on laws defining the scope of such investigative responses.

This paper also summarized published accounts of forensic epidemiology-associated problems and reviewed the use of criminal law in relation to one important example of disease exposure and transmission. The previously published accounts suggest several key issues that 
might arise when epidemiology is used in conjunction with criminal investigations and prosecutions. First, for example, are operational issues in such settings, including the unique approaches to investigation, use of data, and communications employed by epidemiologists, who are focusing on whether there is a public health problem, and by police, who are trying to gather evidence. Second is the challenge prosecutors face in using epidemiologic data. Compounding the difficulties prosecutors may have in explaining the differences between epidemiologic conclusions and legal causation is the potential for epidemiologic data being mischaracterized and misunderstood. The third issue is the spectrum of limitations courts might impose on epidemiologic data offered as evidence during a trial. This spectrum ranges from the exclusion of or uncertainty about admitting such evidence (e.g., on the basis of its being considered too speculative), to no limitations (such as a court permitting the prosecution to present epidemiologic evidence, so long as such data are not viewed as definitively demonstrating guilt).

The experiences and developments included in this paper especially emphasize legal considerations relevant to joint investigations of bioterrorism-related events, such as the anthrax attacks of fall 2001. These considerations, each of which warrant improved understanding through practice and experience, as well as scholarship and analysis, include: the law of entry into residential, business, and workplace settings during concurrent epidemiological and criminal investigations; legal and operational implications if law enforcement first takes charge of a scene, but public health must subsequently engage (or, conversely, the implications when public health is first on scene and law enforcement later enters); other Fourth and Fifth Amendment issues; and establishment of a chain of custody of evidence. In addition, the terrorist attacks of 2001 have prompred some states, such as North Carolina, to examine and modify authorities involving joint law enforcement and public health investigations, as well as intervention considerations, such as restricting freedom of movement.

Issues relating to the prevention of, preparedness for, and response to threats of deliberate uses of biological and chemical agents have implications that previously were uncontemplated by public health practitioners and law enforcement officials alike. One key implication for epidemiologists and other public health practitioners is whether they receive adequate preparation in schools of public health or through in-service and training in other settings to effectively conduct such activities with full knowledge of the powers and limitations of the applicable laws. If not, then there may be a need to enhance the curriculum of schools of public health and other training modalities so that public health practitioners more clearly understand not only the legal principles guiding public health investigations, but also fundamental constitutional safeguards to individual rights and the legal framework for criminal procedure as carried out by law enforcement officials. Reciprocal issues and implications apply to the needs of lawyers, law students, and law enforcement practitioners regarcling principles of public health, epidemiologic investigations, and the role of the laboratory.

An important conclusion emerging from the notion of forensic epidemiology and from the cumulative experiences of published accounts of the investigations cited in this paper is the need for a lowered, more sensitive threshold for considering criminally intentional behavior as a contributing factor in the epidemiologic differential diagnosis of some outbreaks of disease, injury, and death. Innovations in training and other forms of interactive education, intertwined with sound and thorough legal analyses, are necessary to continue strengthening the joint effectiveness of public health and law enforcement investigators in mounting responses to bioterrorism and other threats to public health. 


\section{Table 1. Investigations involving public health and law enforcement, by year, problem, disease- or injury-causing agent, scope of problem, epidemiologic association, and investigation outcome, United States, 1975-2003.}

\begin{tabular}{|c|c|c|c|c|c|c|}
\hline $\begin{array}{c}\text { Year, } \\
\text { author (ref.) }\end{array}$ & Problem / setting & $\mid \begin{array}{c}\text { Implicated or } \\
\text { suspected } \\
\text { disease- }- \\
\text { injury-causing } \\
\text { agent }\end{array}$ & $\begin{array}{c}\text { Magnitude / } \\
\text { scope of problem }\end{array}$ & $\begin{array}{l}\text { Epidemiologic } \\
\text { association }\end{array}$ & Outcome & Comment \\
\hline 1975, Stross & $\begin{array}{l}\text { Over 6-week period, } \\
\text { occurrence of striking } \\
\text { increase in incidence } \\
\text { of cardiopulmonary } \\
\text { arrests in Veterans } \\
\text { Administration and } \\
\text { teaching hospital }\end{array}$ & $\begin{array}{l}\text { Pancuronium } \\
\text { bromide }\end{array}$ & $\begin{array}{l}\text { During 6-week } \\
\text { period, } 51 \text { episodes } \\
\text { of cardiac arrest in } \\
35 \text { patients }\end{array}$ & $\begin{array}{l}\text { Cardiopulmonary } \\
\text { arrests were } \\
\text { disproportionately } \\
\text { more likely during } \\
\text { one specific shift }\end{array}$ & $\begin{array}{l}\text { Two nurses indicted } \\
\text { for murder, } \\
\text { attempted murder, } \\
\text { and conspiracy to } \\
\text { commit murder }\end{array}$ & $\begin{array}{l}\text { Authors proposed } \\
\text { surveillance for early } \\
\text { detection of critical } \\
\text { events like } \\
\text { cardiopulmonary } \\
\text { arrests and systematic } \\
\text { examination of events }\end{array}$ \\
\hline $\begin{array}{l}1979-1981, \\
\text { Blaser }^{2}\end{array}$ & $\begin{array}{l}\text { In setting of cluster of } \\
\text { unsolved homicides } \\
\text { and disappearances of } \\
\text { black children, } \\
\text { epidemiologic } \\
\text { investigation } \\
\text { conducted to } \\
\text { determine if this could } \\
\text { assist public safety } \\
\text { officials }\end{array}$ & $\begin{array}{l}\text { Among } \\
\text { victims in } \\
\text { cluster, } \\
\text { asphyxiation } \\
\text { was over- } \\
\text { represented }\end{array}$ & $\begin{array}{l}\text { During 20.5-month } \\
\text { period, } 22 \text { unsolved } \\
\text { homicides and } 2 \\
\text { unsolved } \\
\text { disappearances of } \\
\text { children }\end{array}$ & $\begin{array}{l}\text { Comparing male } \\
\text { victims tó matched } \\
\text { controls, victims } \\
\text { more often ran } \\
\text { errands for money, } \\
\text { and more often alone } \\
\text { on streets or in } \\
\text { shopping centers }\end{array}$ & Not applicable & $\begin{array}{l}\text { Authors suggested } \\
\text { defining risk factors } \\
\text { might help parents } \\
\text { and public safety } \\
\text { authorities take } \\
\text { measures to reduce } \\
\text { risk if problem } \\
\text { recurred }\end{array}$ \\
\hline $\begin{array}{l}\text { 1980-1981, } \\
\text { Buehler }^{3}\end{array}$ & $\begin{array}{l}\text { Nurse on cardiology } \\
\text { ward of children's } \\
\text { hospital was arrested } \\
\text { and accused of } \\
\text { administering } \\
\text { overdoses of digoxin } \\
\text { to four patients who } \\
\text { had died }\end{array}$ & Digoxin & $\begin{array}{l}\text { Over 9-month } \\
\text { period, mortality rate } \\
\text { for patients on ward } \\
\text { was nearly four } \\
\text { times that in } \\
\text { preceding } 54 \\
\text { months, with risk } \\
\text { significantly } \\
\text { increased during one } \\
\text { specific shift }\end{array}$ & $\begin{array}{l}\text { Strong association } \\
\text { between infant } \\
\text { deaths and duty } \\
\text { times of particular } \\
\text { nurse }\end{array}$ & $\begin{array}{l}\text { Despite documented } \\
\text { increased risks, } \\
\text { cause of epidemic } \\
\text { remained unclear }\end{array}$ & $\begin{array}{l}\text { Study results } \\
\text { suggested hospital } \\
\text { strengthen central } \\
\text { control over } \\
\text { medication } \\
\text { dispensing procedures } \\
\text { and systematically } \\
\text { monitor deaths by } \\
\text { time and place within } \\
\text { hospital }\end{array}$ \\
\hline $\begin{array}{l}984, \\
\text { Sacks }\end{array}$ & $\begin{array}{l}\text { Cluster of unexplained } \\
\text { deaths during 2-week } \\
\text { period in nursing } \\
\text { home patients }\end{array}$ & Undetermined & $\begin{array}{l}\text { In 54-bed nursing } \\
\text { home, during } 2- \\
\text { week period, } 12 \\
\text { patients died where, } \\
\text { based on previous } \\
\text { mortality patterns, } \\
\text { only } 2.5 \text { deaths were } \\
\text { expected for whole } \\
\text { month }\end{array}$ & $\begin{array}{l}\text { Cause of epidemic } \\
\text { unclear; however, } \\
\text { consistent and strong } \\
\text { association between } \\
\text { duty times of two } \\
\text { nurses and onsets of } \\
\text { terminal episode and } \\
\text { times of patient } \\
\text { deaths }\end{array}$ & $\begin{array}{l}\text { Authors noted that } \\
\text { although possible } \\
\text { criminal activity was } \\
\text { considered by local } \\
\text { authorities before } \\
\text { public health } \\
\text { investigation began, } \\
\text { epidemiologic study } \\
\text { cannot determine } \\
\text { whether intentional } \\
\text { acts committed } \\
\text { against patients }\end{array}$ & $\begin{array}{l}\text { Authors } \\
\text { recommended } \\
\text { continuing } \\
\text { epidemiologic } \\
\text { surveillance of } \\
\text { adverse outcomes in } \\
\text { nursing homes }\end{array}$ \\
\hline \multicolumn{7}{|c|}{ 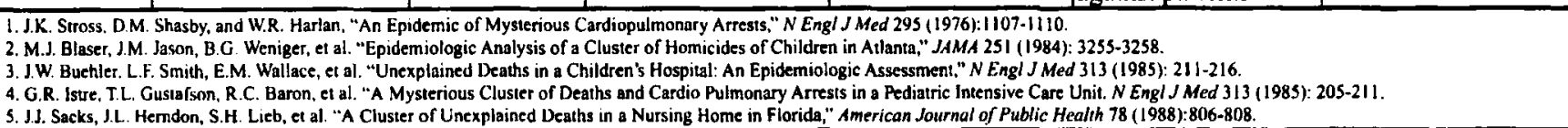 } \\
\hline
\end{tabular}




\section{Table 1. (continued) Investigations involving public health and law enforecement, lyy year, problem, discase- or injury-causing agent, scope of problem, epidemiolugic association, and investigation outcome, United States, 1975-20103.}

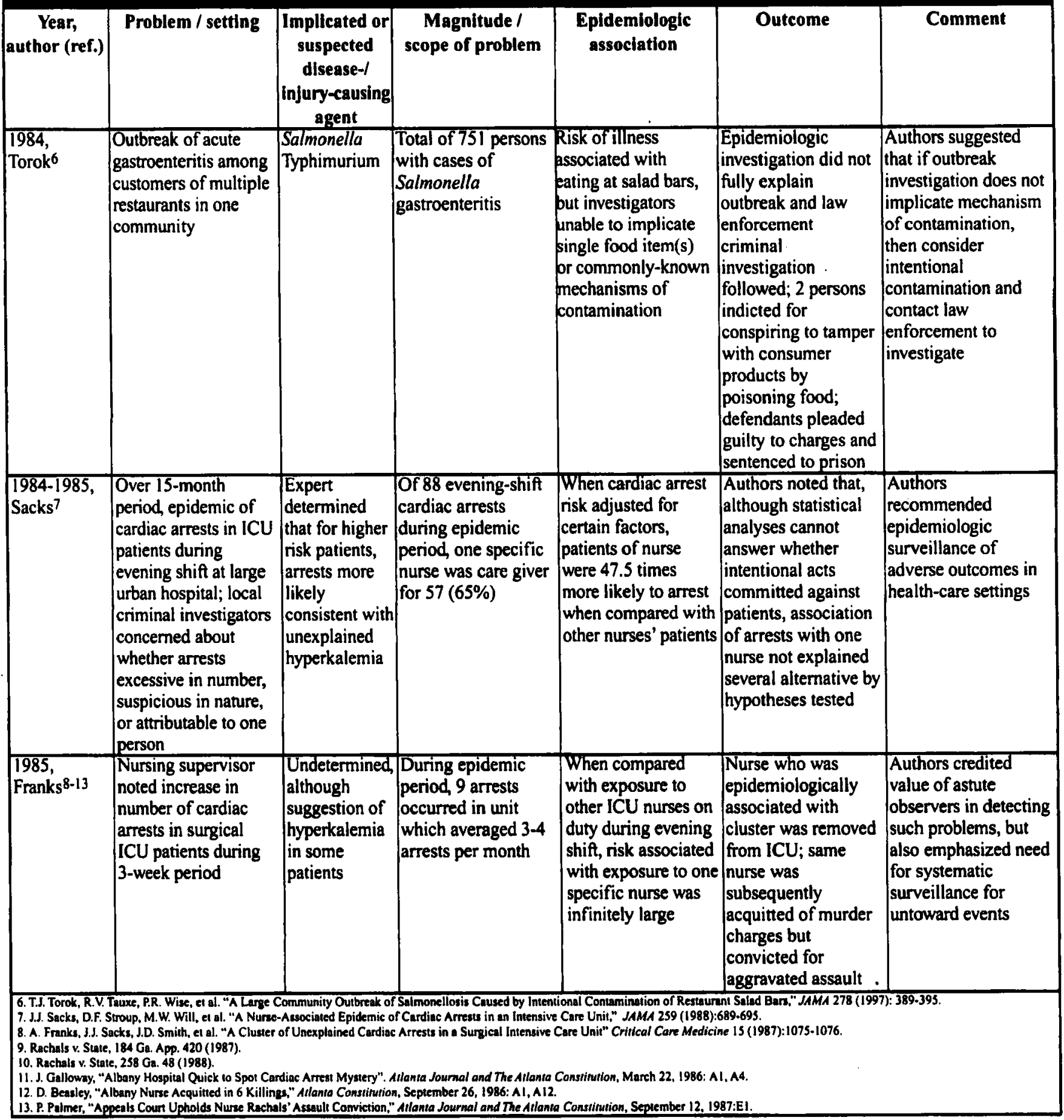




\section{Table 1. (continued) Investigations involving public health and law enforcement, by year, problem, disease- or injury-causing agent, scope of problem, epidemiologic association, and investigation outcome, United States, 1975-2003.}

\begin{tabular}{|c|c|c|c|c|c|c|}
\hline $\begin{array}{c}\text { Year, } \\
\text { author (ref.) }\end{array}$ & Problem / setting & $\begin{array}{c}\text { Implicated or } \\
\text { suspected } \\
\text { disease-/ } \\
\text { injury-causing } \\
\text { agent }\end{array}$ & $\begin{array}{c}\text { Magnitude / } \\
\text { scope of problem }\end{array}$ & $\begin{array}{l}\text { Epidemiologic } \\
\text { association }\end{array}$ & Outcome & Comment \\
\hline $\begin{array}{l}1996, \\
\text { Kovalovic } 14,15\end{array}$ & $\begin{array}{l}\text { Over 3-day period, } \\
\text { laboratory workers a } \\
\text { large medical center } \\
\text { had severe } \\
\text { gastroenteritis caused } \\
\text { by rarely identified } \\
\text { organism }\end{array}$ & $\begin{array}{l}\text { Shigella } \\
\text { dysenteriae } \\
\text { type } 2\end{array}$ & $\begin{array}{l}\text { Of } 45 \text { laboratory } \\
\text { staff, } 12(27 \%) \text { had } \\
\text { severe acute, } \\
\text { diarrheal illness }\end{array}$ & $\begin{array}{l}\text { All } 12 \text { persons who } \\
\text { ate pastries placed in } \\
\text { lab staff break room } \\
\text { became ill compared } \\
\text { with none of } 33 \text { who } \\
\text { did not eat, resulting } \\
\text { in undefined relative } \\
\text { risk }\end{array}$ & $\begin{array}{l}\text { Pastries most likely } \\
\text { contaminated by } \\
\text { lab's stock culture; } \\
\text { lab worker indicted } \\
\text { and charged with } \\
\text { first-degree felony } \\
\text { of tampering with } \\
\text { consumer product }\end{array}$ & $\begin{array}{l}\text { Authors underscored } \\
\text { need for precautions } \\
\text { to prevent inadvertent } \\
\text { or intentional } \\
\text { contamination from } \\
\text { highly pathogenic } \\
\text { lab specimens }\end{array}$ \\
\hline $\begin{array}{l}\text { 1998-1999, } \\
\text { Buchholz }^{16}\end{array}$ & \begin{tabular}{|l|} 
County health \\
department notified \\
about and investigated \\
two clusters of \\
persons with acute \\
gastrointestinal illness \\
with onset soon after \\
eating at one \\
restaurant
\end{tabular} & $\begin{array}{l}\text { Methomyl } \\
\text { lighly toxic } \\
\text { arbamate } \\
\text { esticide) }\end{array}$ & $\begin{array}{l}\text { Total of } 107 \text { persons } \\
\text { met case definition } \\
\text { of illness during } \\
\text { outbreak period }\end{array}$ & $\begin{array}{l}\text { Methomyl identified } \\
\text { in salt, and risk of } \\
\text { illness proportionate } \\
\text { to levels of salt } \\
\text { patrons added to } \\
\text { food; presence of } \\
\text { one cook associated } \\
\text { with shifts during } \\
\text { which cases } \\
\text { occurred }\end{array}$ & $\begin{array}{l}\text { Epidemiologists } \\
\text { considered possible } \\
\text { intentional outbreak } \\
\text { and unable to } \\
\text { identify how salt } \\
\text { contamination could } \\
\text { occur } \\
\text { unintentionally; } \\
\text { police initiated } \\
\text { criminal } \\
\text { investigation }\end{array}$ & $\begin{array}{l}\text { Authors noted one } \\
\text { implication of this } \\
\text { outbreak is need to } \\
\text { strengthen laboratory } \\
\text { and public health } \\
\text { capacity to recognize } \\
\text { and control toxin- } \\
\text { related outbreaks }\end{array}$ \\
\hline $\begin{array}{l}2001, \\
\text { Jernigan } 17-18\end{array}$ & $\begin{array}{l}\text { Following terrorist } \\
\text { attacks in fall } 2001, \\
\text { envelopes containing } \\
B \text {. anthracis spores } \\
\text { mailed to news media } \\
\text { companies and } \\
\text { government officials }\end{array}$ & B. anthracis & $\begin{array}{l}\text { Total of } 22 \text { cases of } \\
\text { anthrax (1 } 1 \\
\text { inhalational and } 11 \\
\text { cutaneous), } \\
\text { including } 5 \text { fatal } \\
\text { cases; } 20 \text { cases were } \\
\text { mail handlers or } \\
\text { worked in settings } \\
\text { where mail } \\
\text { processed; } \\
\text { approximately } \\
32,000 \text { persons } \\
\text { initiated anti- } \\
\text { microbial } \\
\text { prophylaxis }\end{array}$ & $\begin{array}{l}\text { B. anthracis isolates } \\
\text { from envelopes, } \\
\text { patient specimens, } \\
\text { and environmental } \\
\text { samples } \\
\text { indistinguishable by } \\
\text { molecular subtyping }\end{array}$ & $\begin{array}{l}\text { it time of press for } \\
\text { l is manuscript, no } \\
\text { uspect(s) had yet } \\
\text { een indicted under } \\
\text { aderal terrorism } \\
\text { tatutes for criminal } \\
\text { se of biologic } \\
\text { gents in this attack }\end{array}$ & $\begin{array}{l}\text { Authors noted need } \\
\text { for continued } \\
\text { collaboration between } \\
\text { public health and law } \\
\text { enforcement } \\
\text { regarding } \\
\text { bioterrorism-related } \\
\text { anthrax }\end{array}$ \\
\hline $2003, \mathrm{CDC}^{19}$ & $\begin{array}{l}\text { Supermarket notified } \\
\text { state and federal } \\
\text { agencies of planned } \\
\text { recall of ground beef } \\
\text { because of customer } \\
\text { complaints of acute } \\
\text { illness after eating } \\
\text { product; } \\
\text { supermarket's } \\
\text { laboratory then } \\
\text { identified nicotine as } \\
\text { ground beef } \\
\text { contaminant }\end{array}$ & Nicotine & $\begin{array}{l}\text { At least } 92 \text { persons } \\
\text { had illness meeting } \\
\text { case definition, } \\
\text { including one with } \\
\text { atrial fibrillation and } \\
\text { one with complaint } \\
\text { of rectal bleeding. }\end{array}$ & $\begin{array}{l}\text { High concentrations } \\
\text { of nictoine detected } \\
\text { in ground beef } \\
\text { samples submitted } \\
\text { by families with ill } \\
\text { persons }\end{array}$ & $\begin{array}{l}\text { Grand jury } \\
\text { indictment for arrest } \\
\text { of person } \\
\text { (supermarket } \\
\text { employee) accused } \\
\text { of poisoning meat } \\
\text { with insecticide } \\
\text { containing nicotine }\end{array}$ & $\begin{array}{l}\text { Report emphasized } \\
\text { need for physicians to } \\
\text { immediately report } \\
\text { clusters of poisonings } \\
\text { when presenting } \\
\text { symptoms unusual, } \\
\text { and for multiple } \\
\text { agency coordination } \\
\text { in responding to such } \\
\text { events }\end{array}$ \\
\hline \multicolumn{7}{|c|}{ 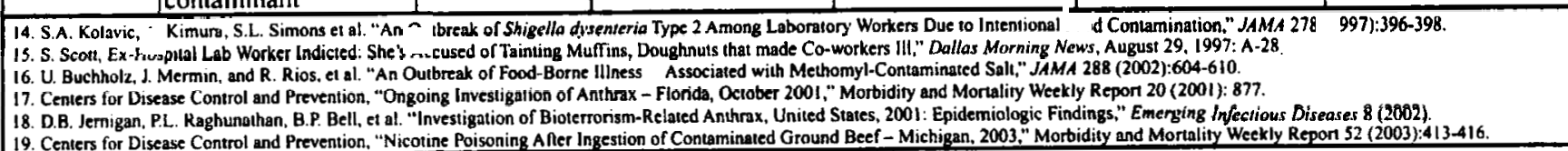 } \\
\hline
\end{tabular}




\section{Talsle 2. Cinursc (Objectives - "Forensic Epiolemiology" Training}

Criminal and Epidemiological Investigative Methods

Det: strate an understanding of the similarities and differences in public health and law enforcement investigative goals and methods

Show an understanding of crime scene procedures

Describe specimen collection and establishment of chain of custody of evidence

Demonstrate an understanding of environmental testing

Understand the inclusion of "intentionality" in the epidemiologic differential diagnosis and investigation

Operations and Procedures

Demonstrate an understanding of controlling laws and sources of authorities for actions

Demonstrate an understanding of legal issues surrounding bioterrorism

Determine jurisdictional lead responsibilities

Identify additional resources to call and when to call

Recognize when to involve the other discipline after the problem is acknowledged

Coordinate public health and law enforcement during responses and investigations

Coordinate local, state, and federal resources

Describe on-scene control measures and interventions

\section{Communications}

Communicate and share information between law enforcement and public health

Differentiate between treatment of information (e.g., privacy, confidentiality, public disclosure)

Describe media relations and risk communication

\section{ReFERENCES}

1. J.K. Stross, D.M. Shasby, and W.R. Haslan, "An Epidemic of Mysterious Cardiopulmonary Arrests," NEngl JMed 295 (1970):1107-1110.

2. J.C. Butler, M.L. Cohen, C.R. Friedman, et al., "Collaboration Berween Public Health and Law Enforcement: New Paradigms and Partnerships for Bioterrorism Planning and Response," Emerging Infectious Diseases 8 (2002):1152-1156.

3. U.S. House Armed Services Committee, Hearing on Chemical and Biological Weapons, 20 October 1999. (Washington; Government Printing Office, 1999); L.K. Altman, G. Kolata, "A Nation Challenged: Anthrax Anthrax Missteps Offer Guide to Fight Next Bioterror Battle," New York Times. January 6, 2002: A1.

4. E. Moscoso, "West Nile Outbreak not Terrorism, Experts Say - Officials Dismiss Bioweapons Theory," Atlanta Journal-Constitution. September 14, 2002: A5.

5. Model State Emergency Health Powers Act. December 21, 2001. Available at http://www public healthlaw.net. (last visited June 27, 2003); L.O. Gostin, J.W. Sapsin, S.P. Teret et al. "The Model State Emergency Health Powers Act: Planning for and Response to Biotertorism and Naturally Occurring Infectious Diseases. JAMA 288 (2002): 622-628; G.J. Annas, "Bioterrorism, Public Health, and Civil Liberties," N Engl JMed 346 (2002): 1337-1342.

6. S. Loue, Forensic Epidemiology: A Comprebensive Guide for Legal and Epidemiology Professionals (Carbondale and Edwardsville: Southern Illinois University Press, 1999).

7. K. Alibek and S. Handelman, Biobazard (New York: Random House, 1999): pp. $x$.
8. U.S. House, supra note 3.

9. Altman, supra note 3.

10. J.M. Last, A Dictionary of Epidemiology, 2nd ed. (New York: Oxford University Press, 1988).

11. P.B. Gove, ed. Webster's Third New International Dictionary (Springfield, Mass.: G. \& C. Merriam Company, 1976).

12. Last, supra note 10.

13. American Academy of Microbiology, Microbial Forensics: A Scientific Assessment. Available at http:// www.asmusa.org/acasrc/aca1.htm. (last visited June 27, 2003).

14. Stross, supra note 1. See also M.J. Blaser, J.M. Jason, B.G. Weniger, et al. "Epidemiologic Analysis of a Cluster of Homicides of Children in Atlanta," JAMA 251(1984): 3255-3258; J.W. Buehler, L.F. Smith, E.M. Wallace, et al. "Unexplained Deaths in a Children's Hospital: An Epidemiologic Assessment," NEngl JMed 313 (1985): 211216; G.R. Istre, T.L. Gustafson, R.C. Baron, et al. "A Mysterious Cluster of Deaths and Cardio Pulmonary Arrests in a Pediatric Intensive Care Unit. NEngl J Med 313 (1985): 205-211; J.J. Sacks, J.L. Herndon, S.H. Lieb, et al. "A Cluster of Unexplained Deaths in a Nursing Home in Florida," American Journal of Public Health 78 (1988):806808; T.J. Torok, R.V. Tauxe, P.R. Wise, et al. "A Large Community Outbreak of Salmonellosis Caused by Intentional Contamination of Restaurant Salad Bars," JAMA 278 (1997): 389-395; J.J. Sacks, D.F. Stroup, M.W. Will, et al. "A Nurse-Associated Epidemic of Cardiac Arrests in an Intensive Care Unit," JAMA 259 (1988):689-695; A. Franks, J.J. Sacks, J.D. Smith, et al. "A Cluster of Unexplained Cardiac Arrests in a Surgical Intensive Care Unit" Critical Care 
Medicine 15 (1987):1075-1076. See also personal communication from Adele L. Franks, M.D. to Richard A. Goodman, M.D., on June 6, 2003. For examples from case law, see Rachals v. State, $184 \mathrm{Ga}$. App. 420 (1987) and Rachals v. State, $258 \mathrm{Ga}$. 48 (1988). For examples from the press, see J. Galloway, "Albany Hospital Quick to Spot Cardiac Arrest Mystery". Atlanta Journal and The Atlanta Constitution, March 22, 1986: A1, A4; D. Beasley, "Albany Nurse Acquitted in 6 Killings," Atlanta Constitution, September 26, 1986: A1, A12; P. Palmer, "Appeals Court Upholds Nurse Rachals' Assault Conviction," Atlanta Journal and The Atlanta Constitution, September 12, 1987:E1; S.A. Kolavic, A. Kimura, S.L. Simons et al. "An Outbreak of Shigella dysenteria Type 2 Among Laboratory Workers Due to Intentional Food Contamination," JAMA 278 (1997):396-398; S. Scott, Ex-Hospital Lab Worker Indicted: She's Accused of Tainting Muffins, Doughnuts that made Co-workers Ill," Dallas Morning News, August 29, 1997: A-28 and U. Buchholz, J. Mermin, and R. Rios, et al. "An Outbreak of Food-Bome Illness Associated with Methomyl-Contaminated Salt," JAMA 288 (2002):604-610. Finnaly, see also Centers for Disease Control and Prevention, "Ongoing Investigation of Anthrax - Florida, October 2001," Morbidity and Mortality Weekly Report 20 (2001): 877 and D.B. Jernigan, P.L. Raghunathan, B.P. Bell, et al. "Investigation of Bioterrorism-Related Anthrax, United States, 2001: Epidemiologic Findings," Emerging Infectious Diseases 8 (2002); Centers for Disease Control and Prevention, "Nicotine Poisoning After Ingestion of Contaminated Ground Beef - Michigan, 2003," Morbidity and Mortality Weekly Report 52 (2003):413-416.

15. Stross, supra note 1

16. Torok, supra note 14.

17. Morbidity and Mortality Weekly Report 20 (2001), supra note 14; D.B. Jernigan, supra note 14.

18. Stross, supra note 1.

19. Stross, supra note 1 .

20. Stross, supra note 1.

21. Buehler, supra note 14; Istre, supra note 14; Sacks, "A Cluster of Unexplained Deaths in a Nursing Home in Florida," supra note 14; Sacks, "A Cluster of Unexplained Cardiac Arrests in a Surgical Intensive Care Unit," supra note 14. Franks, supra note 14; Personal communication from Franks, supra note 14; Rachals v. State, supra note 14; Rachals v. State, supra note 14; Galloway, supra note 14; Beasley, supra note 14.

22. Palmer, supra note 14; Franks, supra note 14; Personal communication from Franks, supra note 14; Rachals $v$. State, supra note 14; Rachals v. State, supra note 14; Galloway, supra note 14; Beasley, supra note 14.

23. Rachals v. State, supra note 14; Rachals v. State, supra note 14; Galloway, supra note 14; Beasley, supra note 14; Palmer, supra note 14.

24. Torok, supra note 14.

25. Buchholz, supra note 14 .
26. Torok, supra note 14.

27. 18 U.S.C. $\$ 175 ; 18$ U.S.C. $\$ 178 ; 18$ U.S.C. $\$ 2332 a$.

28. American Academy of Microbiology, supra note 13.

29. Buchholz, supra note 14.

30. 18 U.S.C. $\$ 175$, supra note $27 ; 18$ U.S.C. $\$ 178$, supra note 27; 18 U.S.C. $\$ 2332 a$, supra note 27.

31. Z. Lazzarini, S. Bray, S. Burris, "Evaluating the Impact of Criminal Laws on HIV Risk Hehavior," Joumal of Law, Medicine E Etbics 30 (2002): 239-255.

32. Lazzarini, supra note 31.

33. R. Smith, "S.D. Gay Couple Faces Prison for Exposing Others to HIV: ACLU Urges "Caution" in Pros-. ecutions when Infection not yet Proven," Washington Blade, May 24, 2002.

34. "CDC Joins HIV Investigation in NY," United Press Internationl, Thursday, October 30, 1997, <http:// www.aegis.com?news/upi/1997/UP971019.html> (last visited June 25, 2003).

35. Centers for Disease Control and Prevention, "Cluster of HIV-Positive Young Women - New York, 1997-1998," Morbidity and Mortality Weekly Report 48 (1999): 413-416.

36. Lazzarini, supra note 31

37. L. Richardson, "Man Faces Felony Charge of Exposing Girl to H.I.V," New York Times, August 20, 1998: B3; NY Penal Code sec. 120.25, Reckless Endangerment in the First Degree.

38. New York State Bill \# A04787 creates the crime of reckless endangerment of the public health for recklessly transmitting HIV/AIDS, available at http://assembly. state.ny.us/leg/?bn=A04787 (last visited November 12, 2003).

39. New York Public Health Law, of 2780-2787 (1999).

40. U.S. v. Moore, 846 F.2d 1163 ( $8^{\text {th }}$ Cir. 1988).

41. U.S. v. Moore, supra note 40.

42. South Dakota Statutes $₫ 22-18-31$.

43. J. Napolitano, "South Dakota: Jail Term for H.I.V. Exposure," New York Times, August 30, 2002: A15.

44. Smith, supra note 33; M. Markus, "A Treatment for the Disease: Criminal HIV Transmission/Exposure Laws," Nova Law Review, 875:23 (Spring, 1999).

45. South Dakota, Legislative tracking, available at: http://legis.state.sd.us/sessions/2003/1019.htm (last visited November 12, 2003).

46. South Dakota House Judiciary Committee Hearing, Testimony of Doneen Hollingsworth, Secretary of Health, South Dakota Department of Public Health, January 24, 2003 available at http://legis.state.sd.us/sessions/ 2003/1019.htm (last visited November 12, 2003); audio testimony-available at http://lightning.state.sd.us:8080/ ramgen/78session/hju08hb1019a.rm (last visited November 12, 2003 and also on file with author; referenced portion from time stamp 3:18 to 3:45).

47. Centers for Disease Control and Prevention, Forensic Epidemiology: Joint Training for Law Enforcement and Public Healtb on Investigative Responses to Bioterrorism, 
Course Managers' Guide. 2003.

48. Centers for Disease Control and Prevention, supra note 14; Jernigan, supra note 14.

49. Torok, supra note 14.

50. Contents of Letter to Sen. Daschle released by FBI on Oct. 23, 2001; for an image of the letter, see <www.fbi.gov/pressrel/pressrel01/102301.htm> (last visited November 12, 2003).

51. Torok, supra note 14.

52. U.S. Constitution, Amendment IV.

53. U.S. Constitution, Amendment V.

54. Camara v. Municipal Court, 387 U.S. 523 (1967).

55. Frank v. Maryland, 259 U.S. 360 (1959).

56. Camara v. Municipal Court, supra note 54; See v. City of Seattle, 387 U.S. 541 (1967).

57. U.S. Constitution, supra note 52.

58. O'Connor v. Ortega, 480 U.S. 709 (1987).

59. Weeks v. United States, 232 U.S. 383 (1914); Gouled v. United States, 255 U.S. 298 (1921).

60. D.A. Christensen, "Warrantless Administrative Searches Under Environmental Laws: the Limits to EPA Inspectors' Statutory Invitation. Environmental Law, 1019 (1996):26.

61. Camara v. Municipal Court, supra note 54.

62. Michigan v. Clifford, 464 U.S. 287 (1984).

63. Michigan v. Clifford, supra note 62.

64. United States v. Branson, 21 F.3d 113 (1994).

65. Ann K. Wooster, Annotation, Validity of Warrantless Administrative Inspection of Business that is Allegedly Closely or Pervasively Regulated: Cases Decided Since Colonnade Catering Corp. v. U.S., 182 A.L.R. FeD. 467 (2002).

66. Payton v. New York, 445 U.S. 573 (1980); New York v. Burger, 482 U.S. 691 (1987); Michigan v. Tyler, 436 U.S. 499 (1978); Bumper v. North Carolina, 391 U.S. 543 (1968).

67. Illinois v. Rodriguez, 497 U.S. 177 (1990).

68. Schneckloth v. Bustamonte, 412 U.S. 218 (1973).

69. Michigan v. Tyler, supra note 66.

70. Payton v. New York, supra note 66; Kirk v. Louisiana, 536 U.S. 635, 638 (2002).
71. Illinois v. Gates, 462 U.S. 213 (1983).

72. Michigan v. Tyler, supra note 66.

73. Kroplin v. Truax, 165 N.E. 498 (1929); Jacobson v. Massachusetts, 197 U.S. 11 (1905); North American Cold Storage Co. v. City of Chicago, 211 U.S. 306 (1908); Compagnie Francaise de Navigation a Vapeur v. Board of Health, 186 U.S. 380 (1902).

74. New York v. Burger, supra note 66.

75. Marshall v. Barlow, Inc., 436 U.S. 307 (1978).

76. F.P. Grad, The Public Health Law Manual, $2^{\text {nd }}$ Edition. (APHA, 1990:135) citing United States v. Biswell, 406 U.S. 311.

77. United States v. Moss, 963 F.2d 673 (4th Cir. 1992).

78. United States v. Mendenhall, 446 U.S. 544,554 (1980).

79. Doe v. Heck, 327 F. 3d 492 (7th Cir. 2003).

80. Doe v. Heck, supra note 79.

81. Mirancla v. Arizona, 384 U.S. 436 (1960); Dickerson v. United States, 530 U.S. 428 (2000).

82. Oregon v. Elstad, 470 U. S. 298 (1985).

83. Miranda v. Arizona, supra note 81.

84. Florida v. Bostick, 501 U.S. 429 (2001).

85. New York v. Quarles, 467 U.S. 649 (1984).

86. T.A. Mauet, Trial Techniques (Aspen, Colorado: Aspen Publishers, 2000).

87. L.O. Gostin, supra note 5.

88. North Carolina General Statute (N.C.G.S.) \$130A-475.

89. N.C.G.S. $\$ 130 \mathrm{~A}-476$.

90. N.C.G.S., supra note 89; N.C.G.S. \$130A-143.

91. N.C.G.S. \$130A-143(7).

92. N.C.G.S., supra note 91.

93. N.C.G.S. \$130A-25.

94. N.C.G.S. $\$ 15 A-401(b)(4)$.

95. N.C.G.S. \$15A-534.5.

96. Stross, supra note 1.

97. Kolavic, supra note 14; Scott, supra note 14; Buchholz, supra note 14; Centers for Disease Control and Prevention,"supra note 14; Jernigan, supra note 14; Centers for Disease Control and Prevention, supra note 14. 